\title{
Regulation of proliferation and survival of B-lymphocytes by Ebf1 - implications in leukaemia
}

Ildikó Győry ${ }^{1 *}$, Rudolf Grosschedl ${ }^{2}$

From Birminghm Cancer Epigenetics Conference; Translational Opportunities

Birmingham, UK. 16 May 2013

Ebf1 is an important determinant of the specification of B lymphocytes. However, expression of this transcription factor is not limited to early B lymphopoiesis and constitutive deletion of Ebf1 results in developmental block and embryonic lethality. To gain insight into additional functions of Ebf1, we inactivated Ebf1 at various stages of differentiation using a Cre-lox-regulated conditional knockout allele.

We found that Ebf1 is required for the proliferation and survival of pro-B cells and peripheral B-cell subsets. In Ebf1-deficient pro-B cells, overexpression of the prosurvival genes $\mathrm{Bcl} 2$ or $\mathrm{BclXL}$ was not sufficient for cellsurvival.

We found a remarkable clonal difference in the cell cycle response of transformed pro-B cells upon induced Ebf1-deletion: one cell type arrested in the G(1) phase and the other type died without arrest. Unexpectedly, the cycling cell-type survived upon c-myb overexpression, in contrast to the other transformed clone type or to primary pro-B cells, showing cell cycle arrest as well. This point to two different Ebf1 regulated cell-cycle-coupled cell survival pathways. As inactivating mutations of the $E B F 1$ gene are frequent in acute lymphoblastic leukaemia, elucidating the role of Ebf1 in cell cycle and survival could provide novel means of intervention in the growth of leukaemia cells.

\section{Authors' details}

${ }^{1}$ University of Leicester, Leicester, Leicestershire, LE1 9HN, UK. ${ }^{2}$ Max Planck Institute of Immunobiology and Epigenetics, Freiburg, Baden-Württemberg, D-79108, Germany.

* Correspondence: ig56@Leicester.ac.uk

'University of Leicester, Leicester, Leicestershire, LE1 9HN, UK

Full list of author information is available at the end of the article
Published: 19 August 2013

doi:10.1186/1868-7083-5-S1-S4

Cite this article as: Györy and Grosschedl: Regulation of proliferation and survival of B-lymphocytes by Ebf1 - implications in leukaemia. Clinical Epigenetics 2013 5(Suppl 1):S4.
Submit your next manuscript to BioMed Central and take full advantage of:

- Convenient online submission

- Thorough peer review

- No space constraints or color figure charges

- Immediate publication on acceptance

- Inclusion in PubMed, CAS, Scopus and Google Scholar

- Research which is freely available for redistribution

\section{Biomed Central}

